German Buenos Aires, 1900-1933

Social Change and Cultural Crisis 
The Texas Pan American Series 


\title{
German Buenos Aires, 1900-1933 Social Change and Cultural Crisis
}

\author{
By Ronald C. Newton
}

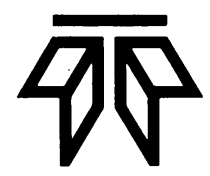

University of Texas Press, Austin \& London 
The Texas Pan American Series is published with the assistance of a revolving publication fund established by the Pan American Sulphur Company.

The publication of this book was assisted by a grant from the Andrew W. Mellon Foundation.

Library of Congress Cataloging in Publication Data Newton, Ronald C 1933-

German Buenos Aires, 1900-1933.

(Texas Pan American series)

Bibliography: $p$.

Includes index.

1. Germans in Buenos Aires. 2. Buenos Aires-Social conditions. I. Title.

F3001.9.G3N48 301.45'13'10821 77-7206

ISBN 0-292-72714-3

Copyright (C) 1977 by the University of Texas Press

All Rights Reserved

Printed in the United States of America 
To the memory of my friend

JOHN HUNTER ARMSTRONG 
THIS PAGE INTENTIONALLY LEFT BLANK 